\title{
AN HISTORICAL EXAMINATION OF ALBERTA'S LEGAL SYSTEM - THE FIRST SEVENTY-FIVE YEARS
}

\author{
W. G. MORROW*
}

\begin{abstract}
This article was written in 1980 to commemorate Alberta's 75 th year as a Province of Canada. The legal issues which arose during the past 75 years, both in criminal law and in civil litigation, reflect the social, economic and political development of the Province. The author provides an historical retrospective of those issues, drawing details from personal experience gained throughout his legal career in Alberta and the Northwest Territories.
\end{abstract}

\section{INTRODUCTION}

The year 1980 was celebrated many ways as Alberta's seventy-fifth birthday. It seems to me that some attempt should be made to look at these seventy-five years from the point of view of legal history and development.

We could study the historical development of Alberta from many different approaches. For example, we could look at economic growth. Here we would follow the changes, sometimes slow, but more often rapid, from the period of a fur-trade economy, through those years of colonization and land settlement when Alberta's vast agricultural area was homesteaded and transcontinental railways with their feeder lines came to criss-cross the whole area, until finally in the present period we see the province as a major energy source with oil and gas wells supporting not only a large part of Canada but along with it a very profitable petrochemical industry.

Or our study could be done with more of a political slant. Here it would not take very long until we noticed how the province moved rather rapidly from a frontier community into a fully settled area, just in time to feel and suffer the impact of the depression, often described as "the hungry thirties". Here the political scene would show a struggling farmer government give place to a populist-type Social Credit party with its long hold on power. Then, as the depression faded away and the dependence on agriculture and other forms of primary production gave way to the sophistication of oil wells and pipelines, the political philosophy changed from radical to conservative. So, too, the period of bond defaults and brick buildings gave way to surplus billions being loaned by the province to other provinces and cities of glass-encased skyscrapers.

I am certain there could be other avenues of approach, but I propose to follow what I choose to call the judicial or legal route.

During the full period of Alberta's history as a province there has been a record kept and published of important and even unimportant legal cases. I have lived through most of this period under review - first as the son of a lawyer, then as a lawyer, and finally as a judge, and I have experienced how these law reports or the decisions from the courts reflect the social, economic and political climate and development of the province. They record the day-by-day struggle between citizens and govern-

* The late Mr. Justice W.G. Morrow of the Court of Appeal of Alberta. This article is published posthumously, and the editors wish to acknowledge the advice and assistance of Mr. John Cote, of the firm of Reynolds, Mirth \& Cote, Edmonton, in bringing this article to publicaton. 
ment or citizens and citizens. In general it is not the wealthy businessman or large corporation who fights the battles for liberty, or against intrusions against property. No, it is more than likely an ordinary citizen, a farmer or a housewife, who will be the one to stand up to be counted and will take the issue to court.

What follows is my attempt to illustrate Alberta's history through the judicial decision route. This does not come from in-depth research on a scientific basis; rather, this is my own quick and rather cursory glance through the law reports to which I have added some of my own personal reflections.

\section{THE EARLY YEARS}

When Alberta was carved from the Northwest Territories in 1905 it said good-bye to a system of justice which had been administered for the most part by Justices of the Peace, Stipendiary Magistrates, and Judges of the old Supreme Court of the Northwest Territories. ' The Alberta Act of 1905 provided that the laws of the Territories continued in Alberta until changed. ${ }^{2}$ This, by virtue of the North-West Territories Act, 1886, as amended, ${ }^{3}$ meant that the laws of England as they stood on July 15, 1870, insofar as practicable, were to apply in the Territories. This cut off date remains with us, but, of course, as each year passes, becomes of less direct importance. ${ }^{4}$

In the earlier years, in particular, the courts had to wrestle with the problems which arose from that provision in the above legislation, for the English laws to govern "in so far as the same are applicable to the Territories". ${ }^{5}$ This phrase made it easy for the Alberta courts to apply a degree of flexibility to their interpretation dictated by the needs of a frontier community. For example, in 1917 Justice Stuart of the Appellate Division in $R$. v. Cyr, a case involving the capacity of a woman's right to preside as a magistrate, shows the attitude of the Court when he says: ${ }^{6}$

In my opinion in a matter of this kind the Courts of this province are not in every case to be held strictly bound by the decisions of English Courts as to the state of the common law of England in 1870. We are at liberty to take cognizance of the different conditions here, not merely physical conditions, but the general conditions of our public affairs and the general attitude of the community in regard to the particular matter in question.

Fortunately, during these formative years the persons attracted to both the Bench and Bar were of high calibre. The result is that we can look back on their efforts in establishing our jurisprudence both as serving the needs of the people at the time and as providing a solid basis for the growth over the ensuing years.

How these early cases reflect those times! Here is just a small sample. In 1905 the Canadian Pacific Railway was prosecuted for breach of the Prairie Fire Ordinance; ${ }^{7}$ a man was prosecuted for shooting a dog; ${ }^{8}$ mort-

1. Royal Bank of Canada v. Scott [1971]4 W.W.R. 491.

2. The Alberta Act, 1905, 4-5 Edward VII, c. 3, s. 16.

3. The North-West Territories Act, R.S.C. 1886, c. 50, s. 48.

4. The Judicature Act, R.S.A. 1970, c. 193, ss. 15, 17.

5. Supra n. 3.

6. R. v. Cyr [1917] 3 W.W.R. 849 , at 857.

7. Consol. Ord. N.W.T. 1905, c. 87. See R. v. C.P.R. (1905) 1 W.L.R. 89.

8. Bremner v. Walker (1905) 2 W.L.R. 347. 
gage priorities as they were spelled out under the new Land Titles statute were examined; 9 a man was prosecuted for supplying liquor to a treaty Indian $;^{10}$ there was a decision on a warranty on a threshing outfit; ${ }^{11}$ a fight over the railway's responsibility to fence; ${ }^{12}$ a case on caveat emptor in a house deal $;^{13}$ a decision as to who had to pay for building the bridges over irrigation canals; ${ }^{14}$ one on theft of cattle; $;{ }^{15}$ and many more.

As might be expected, even in those early days cases were being brought to oust councillors from municipal office; ${ }^{16}$ and already constitutional cases were emerging. One arose out of a battle between the federal and provincial governments as to which railway, federal or provincial, had the primary right to cross the other.$^{17}$ Another suit decided whether the province could legislate in respect of railway bonds and securities, or whether a province could not interfere with securities of a federally incorporated company. The province won that one. ${ }^{18}$

Looking back from the present period of high inflation and depreciated money values, it seems remarkable indeed to find a 1905 decision where an action to enforce a land contract covering sixty acres showed the total value of the farm as $\$ 660.00$, the deposit to bind the deal being the handsome sum of $\$ 5.00 .^{19}$ And a year later a real estate agent sued for a total commission of $\$ 208.00$ on the sale of a farm. ${ }^{20}$ These, I should mention, were not small debt cases as we know them now, but actions brought in Supreme Court. And I must refer to a case brought in 1905 where the Court was asked to cite a husband for contempt because he had failed to pay alimony - the alimony being $\$ 25.00$ per month. ${ }^{21}$

The above surely illustrate how the local citizens of the new province were carrying on in those early days. The land was being settled, homesteads were perfected or being bought and sold, new railways competing for the business were criss-crossing the country, and the users of horses, purchasers of cattle, and operators of farm machinery, had to seek the protection of the courts from themselves, from the government, or from what Bob Edwards called the "big bad C.P.R.". And so we leave this first developing stage with just a slight hint of what might be called a harbinger of things to come - way back in 1915: a case involving an oil drilling contract (but no oil).22

9. Re Greenshields Co. (1905) 2 W.L.R. 421. The Act under consideration was The Land Titles Act, 1894, S.C. 1894, c. 28.

10. R. v. Gray (1906) 3 W.L.R. 564; and R. v. Trottier (1913) 6 Alta. L.R. 451.

11. Swayer and Massey Co. v. Thibault (1907) 5 W.L.R. 241.

12. Winterburn v. Edmonton, Yukon \& Pacific Ry. (1908) 1 Alta. L.R. 92.

13. Urch \& Patterson v. Strathcona Horse Repository (1909) 2 Alta. L.R. 183.

14. The King v. The Alberta Railway \& Irrigation Co. (1910) 3 Alta. L.R. 71.

15. R. v. Dubois (1909) 12 W.L.R. 561.

16. Re Clark (1906) 3 W.L.R. 311.

17. Canadian Northern Western Ry. Co. v. C.P.R. (1913) 6 Alta. L.R. 147.

18. The King and The Provincial Treasurer of A lberta v. The Royal Bank of Canada(1911) 4 Alta. L.R. 480.

19. Grierson v. Johnston (1905) 1 W.L.R. 83.

20. McGill v. Levasseur (1906) 4 W.L.R. 14.

21. Galley v. Galley (1905) 1 W.L.R. 155.

22. Fidelity Oil \& Gas Co. Ltd v. Jance Drilling Co. Ltd. (1916) 9 Alta. L.R. 439. 
Moving along a few years, the battles over horses, cattle and farm machinery, began slowly to give way to a more sophisticated type of human behaviour, or misbehaviour. The arrival of the horseless buggy introduced a new perspective. In the earliest cases, the bias seemed to be against the car and in favor of the buggy, but this soon changed. By 1917, the first case covering a collision between a street car and a car was reported $^{23}$ and a year later a judge had to arbitrate who was to blame where two buggies passed on a bridge and the frightened horse drawing one plunged off that bridge. ${ }^{24}$

A maturing social structure was to be seen developing in actions testing the application of new types of legislation dealing with social problems. Reform was in the air. In one case dangerous working conditions came up along with the problem of what law was to apply, that old 1870 English law, or The Workmen's Compensation Act, newly passed in 1908.25

In 1909 a statute was passed called The Children's Protection Act, ${ }^{25 a}$ and not much later an action was brought to test its effect on the rights of a parent. ${ }^{26}$ About the same time the jurisdiction of "colonial courts" was tested again where an issue arose as to who had the jurisdiction to decide guardianship, the child being outside Alberta, but the father here. ${ }^{27}$

There was an emerging awareness of inadequacies in the protection and treatment of women. Some people were inclined to blame early trends toward "radicalism" on the high altitude, Alberta being generally spread over the highest of the three prairie steppes. But I prefer to attribute the phenomenon to the fact that Alberta, as Canada's last frontier, had citizens, male and female, who observed first hand how the "weaker" member of the sexes was in every observable fashion carrying an equal load in carving out the new homes in the west. And the Alberta judges, themselves being of this frontier, appreciated the equality of the effort and the need to give it some recognition in the application of legal precepts, so far as they could. And some of Alberta's new legislation reflected this as well. Today it would be and is described as inadequate; but Rome was not built in a day.

So we have cases interpreting the new Married Women's Relief Act; ${ }^{28}$ the $C y r$ case, already referred to, where notwithstanding the English law the Alberta Court held that a woman was perfectly capable of acting as a Magistrate ${ }^{29}$ and a new Dower Act which gave a wife some protection in the homestead, be it farm or house..$^{30}$

The ingenuity of Alberta's lawyers and judges achieved a major breakthrough in domestic relations in 1918. This was one time when the English law before 1870 was a help. By 1918 Albertans were suffering the

23. Morgan v. City of Edmonton [1917] 2 W.W.R. 591.

24. Lusk v. Calgary and C.P.R. [1918] 1 W.W.R. 188.

25. S.A. 1908, c. 12. See Powell v. Thomas [1918] 3 W.W.R. 901.

25a. S.A. 1909 , c. 12.

26. In re Children's Protecton Act [1918] 3 W.W.R. 512.

27. In re M. [1918] 1 W W.R. 579.

28. S.A. 1910, c. 18. See Re Drewry Estate (1916) 9 W.W.R. 956.

29. Supra n. 6.

30. S.A. 1917, c. 14. See Russell v. Russell [1917] 3 W.W.R. 549; [1918] 2 W.W.R. 672.. 
usual number of domestic problems, but the federal Parliament, with exclusive power over marriage and divorce had not, for reasons best known to the politicians, seen fit to exercise its powers to permit divorce. In what was to become an epochal decision Alberta's Appellate Division in Board v. Board went back to the 1857 Matrimonial Causes Act of England ${ }^{30 a}$ and found that it luckily was part of the law of England applicable to the Territories. Therefore, by virtue of the old 1886 statute above mentioned, it was continued in Alberta. This case was appealed to the Privy Council in England which on May 15, 1919 confirmed the relief already given to the spouses of Alberta by the appeal court. ${ }^{31}$ In some quarters today we hear words disparaging the breadth of vision of our Fathers of Confederation. But may I make the observation that those few choice words carried into the Alberta Act from the North-West Territories Act by Canada's earlier parliamentarians, some of who had sat in government at the time of Confederation, were almost all that disputing husbands and wives had, until a modern Divorce Act was passed in $1968 .{ }^{32}$

There were two other important developments before 1920 in Alberta. One was the effect of the temperance forces on the cultural and social life of Albertans. That of course extended well past 1920 but one case of note should be looked at in passing. To get liquor legally you had to enlist the support of a doctor. Armed with a doctor's prescription, certifying that you required a shot of whisky for health reasons, you could get the much needed relief from your friendly druggist. That was a contributing factor to setting the high plane on which Albertans have always viewed their doctors. At any rate, in 1918, a patient seems to have overdone it. He persuaded his doctor to prescribe a generous supply of his favourite medicine for, of all things, a fishing trip. I am afraid the whole thing ended up ingloriously in court. ${ }^{33}$

Following 1914, Canada was at war. The war period gave rise to many special cases in the courts. One of the first involved a military officer who refused to obey an order of a Supreme Court Judge which required him to appear in court with a draftee in his custody. The draftee had applied for his discharge by way of an habeas corpus application. Needless to say the court order triumphed in the appeal court. ${ }^{34}$ Many an habeas corpus application was launched by a reluctant draftee. A Mr. Lewis succeeded in 1918 by showing that the order-in-council respecting his military service had been passed without the sanction of Parliament. ${ }^{35}$ During this same period we find many cases discussing the application of statutes passed by the Alberta government to give soldiers tax and other relief during their period of service. ${ }^{36}$

By the close of the year 1918, a slight glimmer of what was to come was to be seen in a dispute between the City of Calgary and a new gas company as to how far the City's franchise might extend..$^{37}$

30a. (U.K.), 20 \& 21 Vict., c. 85.

31. Board v. Board [1918] 2 W.W.R. 633; [1919] 2 W.W.R. 940.

32. Divorce Act, S.C. 1967-68, c. 24.

33. R. v. Rose [1918] 3 W.W.R. 950.

34. In re Norton [1918] 2 W.W.R. 865.

35. In re Lewis [1918] 2 W.W.R. 687.

36. Armstrong v. Bradburn [1917]2 W.W.R. 867; General Financial Corporation of Canada v. Wood [1918] 1 W.W.R. 780.

37. Calgary v. Canadian Western Natural Gas [1918] 1 W.W.R. 121. 


\section{AFTER WORLD WAR I}

Between the end of the war and the beginning of the serious depression period, the law reports reflect what I would call a fairly steady growth, a proliferation of new types of legislation, especially in a new reality of life, namely administrative law, and in particular an emergence of review boards of all types. The age of the bureaucrat was not far away.

For example, in 1920, an appeal tested the right of the Public Utilities Commissioners to regulate prices so as to overrule the price set forth in a contract..$^{38} \mathrm{~A} \mathrm{Mr}$. Wah Kee attacked a City of Edmonton early closing bylaw, and succeeded in establishing that a laundry was not included in the definition of stores and shops. ${ }^{39}$ The right to regulate the hours of "temperance bars" in Edmonton came under attack when, appropriately, a Mr. O'Brien became involved in a lawsuit with the Royal George Co. Ltd ${ }^{40}$ There were many attacks on the liquor laws of the time and as well on the Sunday Observance laws imposed in those years. ${ }^{41}$ In 1925 the Appeal Court handed down two decisions under the federal Lord's Day Act. ${ }^{41}$ In one the sale of candy on Sunday was found not to be a work of necessity or mercy and so could be banned, ${ }^{42}$ but the sale of gas did come within the permitted class..$^{43}$ In the latter case the court was able to extend the exemption provided in the statute respecting the "hiring of horses, carriages and small boats" to allow the sale of gasoline necessary for a pleasure drive.

By now Alberta, like so many of its sister provinces, had imported a new legislative concept from the United States. This was the right to file a few sturdy souls who refused to give up without a fight. A Mr. Kolita objected, unsuccessfully, to paying excise tax under the Inland Revenue Act. ${ }^{43 a}$ The authorities prosecuted him for having a still on his premises. ${ }^{44}$ The issue of succession duty arose in Alberta as early as 1919. The estate of a person domiciled in Ontario upon his death was held to be taxable under the Alberta statute in respect of a mortgage on Alberta land. ${ }^{45}$

By now, Alberta, like so many of its sister provinces, had imported a new legislative concept from the United States. This was the right to file a mechanic's lien against property to protect the labourer or the supplier of material. 1919 therefore saw an action brought in the Supreme Court of Alberta to enforce a lien under the 1906 Alberta statute. ${ }^{46}$

And some of the problems that beset our police officers in 1980, namely the enforcement of anti-soliciting laws, seem to have been present even as

38. In re Public Utilities Act [1920] 1 W.W.R. 31; [1921] 1 W.W.R. 656; In re Town of Vegreville [1926] 3 W.W.R. 769.

39. $R$. v. Wah Kee [1920] 3 W.W.R. 656.

40. O'Brien v. Royal George Co. Ltd. [1921] 1 W.W.R. 559.

41. R. v.Nat. BelLiquors Ltd. [1921]1 W.W.R. 136;[1921]1 W.W.R. 563;[1922]2 W.W.R.30; Gold Seal Ltd. v. Dominion Express Co. [1921] 1 W.W.R. 804.

41a. R.S.C. 1906 , c. 153.

42. R. v. Kent [1925] 1 W.W.R. 315.

43. R. v. Cummings [1925] 1 W.W.R. 325.

43a. R.S.C. 1906, c. 1 .

44. R. v. Kolita [1920] 2 W.W.R. 594.

45. $R$. v. Toronto General Trusts Corporation [1919] 2 W.W.R. 354.

46. Trussed Concrete Steel Co. of Canada v. Taylor[1919]2 W.W.R. 123. The statute under consideration was The Mechanics' Lien Act, S.A. 1906, c. 21. 
far back as 1919, although it would seem that in those days there was some requirement on the party to respond to a police request. There was a case in the Supreme Court where the judge held that a person found wandering along a street was not bound to answer as to her character or following but was required to explain why she was there. ${ }^{47}$

By then, too, trade unions were mentioned in the law reports. One case involved a plaintiff employee suing a union in a representative action. ${ }^{48}$ The plaintiff succeeded in his claim that the union was liable for causing his dismissal by threatening his employer with a strike unless the plaintiff was dismissed.

Citizens of Edmonton, familiar with the Groat Road, may be interested to learn that in $1927 \mathrm{Mr}$. Groat felt obliged to sue the City fathers because they were channeling run-off water down the ravine where it passed into the Saskatchewan River. He lost, the Court of Appeal holding that this was within the power of the City. ${ }^{49}$

The ever slow transition of the status of women is reflected once again in two 1928 cases. In the first, a married woman was held liable for furniture that had been bought in her name, the court saying she had full power to bind herself. ${ }^{50}$ But in the second case some doubt was thrown on her status should she want to sue her husband. ${ }^{51}$

During this period the rapid opening up of the farmland could not have taken place without the influx of many thousands of immigrants, particularly so many people from central Europe. These people were anxious to acquire farmland and were prepared to work and work hard. What a tremendous contribution Alberta's Ukrainian, Polish, Ruthenian and other new arrivals made and continue to make. I myself recall visiting many of their farmsteads in the Vilna and Bellis areas, sometime enjoying their ovenight hospitality. The fare was frugal but full of nourishment. These fine people and their struggles are, as well, reflected in the lawsuits of the time. An early defamation case is a good illustration. The Court of Appeal in 1920 had to wrestle with how the alleged slander and actual words and meaning were to be proven and translated for the benefit of an English-speaking court. ${ }^{52}$

By 1921 Alberta's motoring on dirt roads had reached such a degree of development and acceptance that an action was brought to enforce the copyright in an automobile guide. ${ }^{53}$

To anyone living in Alberta in 1980 it should be interesting to know that in 1921 Justice Simmons heard a case involving a dispute as to who could stake claims respecting oil and gas, near Great Slave Lake. ${ }^{54}$ Then the

47. R. v. Levine [1919] 1 W.W.R. 637.

48. Williams v.Local Union No. 1562 United Mine Workers of America[1919]1 W.W.R.217.

49. Groat v.Edmonton [1927]1 W.W.R.882. Mr. Groat lost in the Appellate Division, but appealed to Ottawa and won his case there on the grounds of pollution; and without any Department of the Environment to help him: [1928] 3 D.L.R. 725. In the 1960's the City tried to expand its 107th A venue and Groat Road interchange and was surprised to encounter the garbage dump which had figured so prominently in the 1927 litigation.

50. Reid-Welch Furniture Co. v. Macdonald [1928] 1 W.W.R. 788.

51. Hill v. Hill [1928] 3 W.W.R. 1, 673.

52. Polekyli v. Chromik [1920] 1 W.W.R. 858.

53. Emmett v. Meigs [1921] 1 W.W.R. 35.

54. Nicholson v. Mustard [1921] 2 W.W.R. 412. 
Alberta courts exercised original trial jurisdiction over disputes in the Northwest Territories.

The old frontier spirit could still be found within the court system. In a case involving a trespass by cattle and damage for injuries by one of the persons engaged in driving the offending animals from the premises a unique solution was found. ${ }^{55} \mathrm{It}$ appears from the law report that the parties were assembled at the Court House with their respective counsel but no Supreme Court Judge, or for that matter any judge, was available. The Western Weekly Reports state: ${ }^{56}$

No Judge being available to try the action on the day fixed for trial the parties agreed that Mr.A. Macleod Sinclair, K.C. should hear the case and give judgment. The counsel agreed, and the Judges of the A ppellate Division also assented, that in case either party wished to appeal from Mr. Sinclair's decision to the A ppellate Division objection would not be taken on the gound of jurisdiction by reason of the case being heard by him instead of a Judge of the Court.

Mr. Sinclair dismissed the action and his application of "cow" sense is to be found from his remarks where he says: $:^{57}$

I am of opinion that the damage done by the steer is not of such a nature as is likely to arise from such an animal and that the damages are too remote. But even assuming that a steer, when heated, is likely to attack a human being on foot, I am of opinion that the proximate cause of the injury was the action of the plaintiff in approaching the animal on foot in an endeavour to drive it off his land.

It would appear Albertans were not likely to forget the usefulness of the horse and cowboy for cattle control.

The spirit of rugged individualism so common on the frontier was equally to be found among the members of the Alberta judiciary, as witness a remarkable lawsuit where Justices Horace Harvey and David Lynch Scott went all the way to the Privy Council to find out which of the two Chief Justices was entitled to call himself Chief Justice of Alberta and not merely Chief Justice of the Trial Division. The report found in the 1923 Western Weekly Reports provides not only a good review of the history of the judicial system as it was set up in those formative years but is a good illustration of the vanity of man. ${ }^{58}$

A recurrent problem of course was that of women's rights and I think it was only appropriate that the issue of whether a woman was sufficiently a person so as to entitle her to be appointed to the Canadian Senate should have arisen in Alberta and been resolved by some of our pioneer ladies. I refer to a reference brought before the Supreme Court of Canada which was eventually resolved by the Judicial Committee in London. ${ }^{59}$ The names of the petitioners read like a roster of Alberta's leading ladies of the time and illustrates what these persons were so busy doing in the late 1920's. The appellants to London were: Henrietta Muir Edwards, Vice President for Alberta of the National Council of Women for Canada; Nellie L. McClung and Louise C. McKinney who had been members of the Legislative Assembly of Alberta; Emily F. Murphy, a police magistrate; and Irene Parlby, then a member of both the Legislative Assembly and of the Executive Committee. The legal issue was as to the meaning of "per-

55. Hatton v. Morton [1921] 2 W.W.R. 803.

56. Id.

57. Id. at 807.

58. In re Reference Concerning the Chief Justice of Alberta [1923] 3 W.W.R. 929.

59. In the Matter of a Reference as to the Meaning of the Word "Persons" in Section 24 of the British North A merica Act. 1867[1929] 3 W.W.R. 479. 
sons" in Section 24 of the British North America Act, 1867. Canada's Supreme Court did not think it included female persons but as Lord Sankey, the Lord Chancellor, says in giving the favourable opinion of the Privy Council: ${ }^{60}$

Their Lordships are of opinion that the word "persons" in sec. 24 does include women, and that women are eligible to be summoned to and become members of the Senate of Canada.

These words are particularly noteworthy when contrasted with the position of English women referred to in the same judgment: ${ }^{61}$

In England no woman under the degree of a Queen or a Regent, married or unmarried, could take part in the government of the state. A woman was under a legal incapacity to be elected to serve in Parliament and even if a peeress in her own right she was not, nor is, entitled as an incident of peerage to receive a writ of summons to the House of Lords.

I find one paragraph in the judgment of particular significance wherein their Lordships pointed out what an anomaly it would be if the use of the term "person", occurring in so many parts of our constitution, was to be taken to mean only men. They say: ${ }^{62}$

Again in sec. 133 it it provided that either the English or the French language may be used by any person or in any pleadings in or issuing from any Court of Canada established under this Act and in or from all of any of the Courts of Quebec. The word 'person' there must include females as it can hardly have been supposed that a man might use either the English or the French language but a woman might not.

That Alberta anachronism, the six-man jury rather than the twelveman jury found in other common law jurisdictions, was attacked unsuccessfully in 1930 . Once again recourse was had to the 1886 North-West Territories Act, which provided for six not twelve. During my years as a law student and later as lawyer it was always related to us that the magic number of six came from pressure from Alberta ranchers who objected to giving up twelve men for jury duty, particularly during roundup time.

\section{THE DEPRESSION YEARS}

As we move along from the 1920's into the early 1930's even the number of cases reported drops, which in itself is some indication of the impact of hard times. And, then, of course, we begin to find new types of decisions reported.

Hard times brought with them poverty, unemployment, and relief as it was then called. One of the contests of these days was as to which municipality was required to pay an indigent's hospital account, and so on. Medicare and hospitalization programmes as we know them today were as yet many years down the road. So we find the Edmonton Hospital Board suing the Municipal District of Liberty in 1932 for services rendered to an indigent. ${ }^{63}$ By now the pressure of debt brought about a case in the Alberta Supreme Court where Mr. Justice Ives (the "cowboy" judge) had to decide what furniture belonging to tenants was exempt from seizure. Once again the common law as it was in 1870 was brought into play. ${ }^{64}$ For the first time, litigation emerged over remedial legislation

60. Id. at 495 .

61. Id. at 481 .

62. Id. at 493 .

63. Edmonton Hospital Board v. M.D. of Liberty [1932] 1 W.W.R. 599.

64. Stott v. Raby [1934] 3 W.W.R. 625. 
passed by the provincial government, namely The Debt Adjustment Act. ${ }^{65}$

The depth of the depression was on the country by now and once again we have its reflection in the law reports. Some of the more desperate citizens had organized a "hunger march" for December 4, 1932. I am going to quote from one of the speakers who spoke to the assembled people, about this time, as the language is not too dissimilar to that being spoken outside the Court House in Edmonton in this 22nd of July 1980 as I write this article. As of this day there are contempt proceedings underway before the court, brought against civil servants who are protesting government action. Times may be different but people's behaviour changes little. To get back to the words spoken in 1932, a Mr. Stewart said: $:^{6}$

It is up to you to answer Brownlee's threat of force and violence. The gaols at the present time are filled with workers, gaoled in the worker's movement, all over Canada. To-morrow we shall meet here to give Brownlee his answer. He has sent armed thugs to us ordering us not to parade and he would use force and violence. Comrades, he can't give orders to the workers and poor farmers who have an empty belly. Brownlee is trying to intimidate the workers by stopping a peaceful parade. We shall be peaceful until we are stopped. We always remember the first law of nature is self preservation. If we are attacked we must resist to our utmost; any blame will be on the head of Premier Brownlee should anything be done by the Police to stop us. Comrades, tomorrow will be a great test in the history of the working classes; we must go forward, onward to our gaol which is the emancipation of the workers and poor farmers of Alberta. Do not let the Police, Premier Brownlee and Mayor Knott prevent us from trying to bring our demands before the notice of the public. I appeal to you all to be here to-morrow to support your leaders.

At trial there was a conviction for being a member of an unlawful assembly, a permit for same having been refused. The majority of the Court of Appeal set aside the appellant's conviction on the grounds that the evidence, although clear as to his speeches, was not clear as to the party's being present at the unlawful assembly.

During these tough days Alberta's pioneering legal aid was illustrated by a judgment discussing the meaning of the newly introduced Needy Litigant Rules. ${ }^{67}$ These rules had been passed to give poor persons access to the courts. A far cry from Legal Aid as we know it now, the old rules permitted a poor person, who had the approval of the Needy Litigants Committee (made up of volunteer judges and lawyers) to file documents in court free of charge. His lawyer, also a volunteer, had to agree to work without charge. Many a young lawyer, including myself, gained valuable court experience by offering to help these needy people to seek relief in court.

As the 1930's moved towards the outbreak of war a fundamental change in government implanted its own special brand on Alberta's jurisprudence. This was the "take-over" of the Alberta government by the election of the new Social Credit party under "Bible Bill" Aberhart. For a time the courts became overworked with constitutional cases as the new government attempted to introduce legislation intended to implement their election promises. Much of it was directed at debt reduction, or

65. S.A. 1933, c. 13, repealed S.A. 1937, c. 9, superseded by S.A. 1936 (2), c. 3. See In re Richmond v. Dyck [1934] 3 W.W.R. 735..

66. R. v. Stewart [1934] 1 W.W.R. 423 at 425.

67. Werley v. Rowe [1936] 1 W.W.R. 294. See Rules Relating to Proceedings by or against Poor Persons and Needy Litigants, 0.C. 464-32 (1932) 28 Alta. Gaz. No. 10 at 324.. 
at "hitting" the "fifty big-shots", a phrase frequently heard then to cover all the "bad" elements such as the Eastern based banks.

One of the types of legislation which spawned many suits was the debt adjustment legislation. For example, an action was brought against the Clerk of the Court at Edmonton, Mr. R. P. Wallace, because he tried to obey an order-in-council which purported to authorize the Clerk to refuse to accept for filing any action which might be brought to test the validity of the Alberta debt legislation. ${ }^{68}$ According to the reported case the key words in the order-in-council said: ${ }^{69}$

... the Clerk ... shall not, unless and until authorized so to do by the Lieutenant Governor in Council file or enter ... any Statement of Claim ... which contains any allegation, statement or prayer which in any manner questions or contests the constitutional validity of any Act of the Legislature of the Province....

This was strong language to be used in a federal system where the overlapping of legislation is almost a regular issue before the courts. Justice Ives who heard the matter had no difficulty in declaring the orderin-council to be invalid. But the government of the day would not give up that easily.

There followed a whole series of attempts by the Alberta government to help the poor and the debt-ridden. Some of these efforts were laudable and some appeared frivolous, often giving the appearance of efforts to strike at the critics of government with little real hope of helping the constituents, or indeed of ever being upheld in any court test which would be brought almost as a rule.

Indeed, at one time the Attorney General of the Province, Mr. J.W. Hugill, K.C., suffered too much and walked across the floor of the Assembly to join the opposition. It was during this period that Dean J.A. Weir of the law school would often send students (I was at law school then) from class with the suggestion that we could learn more at the Court House. On one occasion we were sent over to the Legislature, which was then in session, for rumour had it that a certain newspaper reporter called Brown was to be hailed before the bar of the House to be imprisoned without trial for his critical articles. It was heady stuff. And as we milled around outside the closed doors of the Assembly we heard how Chief Justice Horace Harvey had already been approached and had agreed to hear an application for habeas corpus should Brown be incarcerated. But this extreme measure did not take place after all.

I mention only a few of the more important cases of this time - there were too many to list in full - but certainly the constitutional law student will find fertile ground in these years in Alberta.

In Royal Trust Co. v. Attorney General of Alberta Ewing J. held that the 1936 Reduction and Settlement of Debts Act was ultra vires. ${ }^{70}$ In five other actions brought before him at the same time he reached the same conclusion. His judgment was later upheld on appeal. ${ }^{71}$ A more serious

68. Steen v. Wallace [1937] 3 W.W.R. 654.

69. Id at 655 .

70. Royal Trust Co. et al v. A.G. for Alberta et al (1937) 1 W.W.R. 376. The Reduction and Settlement of Debts Act, S.A. 1936(2), c. 2 was subsequently repealed.

71. Sub nom. Credit Foncier Franco-Canadian v. Ross et al and A.G. for Alberta [1937] 2 W.W.R. 353 . 
group of cases emerged where an attempt was made by the government to prohibit action being taken to recover on defaulted securities which had been guaranteed by the provincial government. The statute under fire was the Provincial Guaranteed Securities Interest Act of $1937 .^{71 a}$ In most of these cases the courts struck down the legislation because it was found to be in respect to interest or bankruptcy, which of course had been reserved under the B.N.A. Act to the federal government. ${ }^{72}$

I think it would be an understatement to say the situation had heated up by 1937-1938. By then a statute called The Alberta Social Credit Act, $1937,{ }^{72 a}$ had been passed. Under its authority on September 22, 1937 an order-in-council had been passed for the purpose of setting up and operating a circulation department. One of the functions of this department was to compile leaflets, circulars and booklets for the purpose of informing the people of Alberta about Social Credit. It did not take very long until a number of such circulars and pamphlets were passed around. A particularly offensive one ended up in public circulation, which came to be famous as the Bankers' Toadies leaflet. It resulted in the prosecution for defamatory libel of Messrs. Powell and Unwin, one the fiscal adviser of the government, the other the party whip serving in the legislative assembly. The Attorney General of the Province refused to prefer charges so the matter was brought to court as a private prosecution. Here is the first paragraph of the libel as it is set forth in one of the reported judgments: ${ }^{73}$

\section{Bankers' Toadies}

My child, you should never say hard or unkind things about Bankers' Toadies. God made Bankers' Toadies, just as He made snakes, slugs, snails and other creepy-crawly, treacherous and poisonous things. Never therefore, abuse them - just exterminate them!

Ultimately the two gentlemen concerned ended up spending a few months in the gaol at Ft. Saskatchewan. The Edmonton papers kept the public informed by reporting the weekly visits to the institution by the party faithful.

The Social Credit Government's attempts to protect purchasers from foreclosure through the various debt adjustment statutes caused vendors of land to seek the advice of their lawyers on how to circument these laws. One such scheme involved the use of a lease-option type of agreement in the hope that until the option had been actually exercised there was no agreement or security to which the debt legislation could be made to apply. Abuses grew up and many of the so-called option agreements went so far as to provide that until a final payment there was no agreement. And as you might expect such efforts were bound to reach the court at some time. Mr. Justice Shepherd in 1938 held that to call this new type of document an option was not enough; it was still an agreement for sale. ${ }^{74}$

This same year saw the final judgment come down from the Privy Council with respect to a reference of certain Alberta Bills. ${ }^{75}$ The three

71a. S.A. 1937, c. 12, repealed.

72. Independent Order of Foresters v. Lethbridge Northern Irrigation District [1937] 3 W.W.R. 424; [1938] 2 W.W.R. 194; [1940] 1 W.W.R. 502.

72a. S.A. 1937, c. 10, repealed S.A. 1938 , c. 4.

73. R. v. Unwin [1938] 1 W.W.R. 339 at 340.

74. Bezborodka v. Sebenthal [1938] 2 W.W.R. 83.

75. Reference re Alberta Bills [1938] 3 W.W.R. 337. 
Bills under review were: An Act respecting the Taxation of Banks, An Act to amend or Consolidate the Credit of Alberta Regulation Act, and An Act to Ensure the Publication of Accurate News and Information. The Supreme Court of Canada had held them to be ultra vires and the Judicial Committee had no difficulty reaching the same conclusion.

A very important principle of law of importance to the future was enunciated by the Supreme Court of Canada in its judgment with respect to the Bill affecting the news. Although there is no specific statement in our constitution protecting the freedom of the press the above litigation has given Albertans and Canadians the assurance that it is there and will be protected by the courts in any event. Cannon J. of the Supreme Court of Canada said: ${ }^{76}$

\begin{abstract}
There must be an untrammelled publication of the news and political opinions of the political parties contending for ascendancy. As stated in the preamble of The British North America Act, our constitution is and will remain, unless radically changed, "similar in principle to that of the United Kingdom." At the time of Confederation, the United Kingdom was a democracy. Democracy cannot be maintained without its foundation: free public opinion and free discussion throughout the nation of all matters affecting the State within the limits set by the criminal code and the common law. Every inhabitant in Alberta is also a citizen of the Dominion. The province may deal with his property and civil rights of a local and private nature within the province; but the province cannot interfere with his status as a Canadian citizen and his fundamental right to express freely his untramelled opinion about government policies and discuss matters of public concern. The mandatory and prohibitory provisions of the Press Bill are, in my opinion, ultra vires of the provincial legislature. They interfere with the free working of the political organization of the Dominion. They have a tendency to nullify the political rights of the inhabitants of Alberta, as citizens of Canada, and cannot be considered as dealing with matters purely private and local in that province. The federal parliament is the sole authority to curtail, if deemed expedient and in the public interest, the freedom of the press in discussing public affairs and the equal rights in that respect of all citizens throughout the Dominion. These subjects were matters of criminal law before Confederation, have been recognized by Parliament as criminal matters and have been expressly dealt with by the criminal code. No province has the power to reduce in that province the political rights of its citizens as compared with those enjoyed by the citizens of other provinces of Canada. Moreover, citizens outside the province of Alberta have a vital interest in having full information and comment, favourable and unfavourable, regarding the policy of the Alberta government and concerning events in that province which would, in the ordinary course, be the subject of Alberta newspapers' news items and articles.
\end{abstract}

\title{
V. THE SECOND WORLD WAR
}

The law reports continued to carry judgments relating to efforts by the Alberta government to implement its philosophy into the early 1940's, but World War Two was by now focussing the attention of people in other directions.

By 1941 the country was under rent controls and a case was brought before Mr. Justice G. B. O'Connor to test their applicability to a notice to quit served by a landlord on his tenant. ${ }^{\text {" }}$ A year later Judge Clinton J. Ford of the District Court enforced a conviction for speeding under Regulations put into effect by the Department of Munitions and Supply. ${ }^{78}$

The above cases involved federal legislation but the province played its part as well. So we find a case on whether a soldier's land could be foreclosed, or whether the Soldier's Relief Act protected him. ${ }^{79}$ Another

76. Reference re Alberta Statutes, [1938] S.C.R. 100 at 146.

77. Turrill v. Beaten [1941] 3 W.W.R. 846.

78. R. v. Sawatsky [1942] 3 W.W.R. 337.

79. Canada Life Assurance Co. v. Rieb [1943] 1 W.W.R. 759. See S.A. 1942, c. 146. 
case tested the applicability of the same statute to tax exemptions given to those persons serving their country. ${ }^{80}$

By then, too, the plight of deserted mothers had received the attention of the province and a form of relief was introduced to prevent a woman's having to suffer the delay caused by the existing divorce law. The following extract from the headnote in one case reported at this time will illustrate how the problem was being met: ${ }^{81}$

The Mothers' Allowance Act, R.S.A., 1942, ch. 302, a beneficent statute passed for the benefit, protection and maintenance of children living and being cared for by their mother, does not require a wife who is entitled to live apart from her husband, because of his attachment for and adultery with another woman, to wait before bringing an action for divorce until five years have passed on penalty of losing her chance of a mother's allowance; especially where, as here, she was left in destitute circumstances and had to seek a needly litigant's certificate to try to protect herself and her children.

As the war progressed even prisoners of war came before the courts of Alberta. Police Magistrate Beaumont held that prisoners of war were subject to conviction under the local law for crimes committed while they were attempting an escape. ${ }^{82}$ In 1946 the Court of Appeal held that the Alberta courts were the only tribunals which had jurisdiction to try a prisoner charged with the murder of a fellow prisoner, and that the accused's belief that he was obeying his own military law and disposing of a traitor was no excuse. ${ }^{83}$

It is to be noted in passing that Alberta's pre-eminence in matters respecting Canada's north had not been lost sight of even during the War, as can be seen by an incest case brought before the Court of Appeal in $1944 .{ }^{84}$

\section{THE POST-WAR PERIOD}

By 1946 there were signs of a winding down from both the old-type Social Credit phase and from the War. One case heard before Mr. Justice O'Connor assessed amounts to be paid in respect of Alberta Bonds and Debentures as a result of efforts made to reorganize the provincial debt, ${ }^{85}$ and in another a farmer was allowed to repossess his buildings which, it was unsuccessfully argued, were still covered by the Wartime Rental Regulations. ${ }^{86}$

Various levels of government brought in new forms of legislation to control the intoxicated driver, who made every effort he could to avoid the penalty, particularly if it meant the loss of driving rights. So in 1948 Mr. Justice Boyd McBride wrote one of the first judgments which discussed the rules governing the admissibility of statements of accused and in particular the admissibility of blood samples taken from the body of the man. ${ }^{87} \mathrm{~A}$ higher incidence of automobile accidents also arose as the

80. Dreany v. Edmonton [1943] 2 W.W.R. 173.

81. In re $M c D o n a l d[1943] 2$ W.W.R. 97.

82. R. v. Shindler [1944] 3 W.W.R. 125.

83. R. v. Perzenowski [1946] 3 W.W.R. 678.

84. R. v. Rivet [1944] 2 W.W.R. 132.

85. In re Ramsey Trust Deeds [1946] 1 W.W.R. 510.

86. Can. War Orders \& Reg. 1943, Vol. III, No. 7 (Wartime Prices and Trade Board Order No. 294). See In re Lefor [1946] 2 W.W.R. 649; [1946] 3 W.W.R. 779.

87. R. v. Ford [1948] 1 W.W.R. 404. 
assembly lines in Windsor and Oshawa, relieved of war priorities, turned to catching up on the backlog of car orders. An alert government, alarmed at the number of persons unable to recover damages suffered from automobile accidents in these years, saw fit to introduce an Automobile Accident Indemnity Act in $1947^{87 a}$ and one of the first interpretations on how it was to work came from Mr. Justice Clinton J. Ford in 1948. He held that even though the accident had taken place before the statute had become law it was chargeable to the Fund set up under the Act because the date of the judgment was after the passing of the legislation. ${ }^{88}$

While the motor car provided an impetus to litigation in the late 1940s, by far the biggest change to Alberta was the discovery of oil in Leduc in 1947. The problems which evolved from the oil and gas play then starting were complex and difficult. Even as Alberta celebrated its seventy-fifth anniversary there was no sign of any falling off in the litigation related to the production of petroleum products.

There had been little if any experience in this country with oil terms and oil litigation, but from 1947 on our courts developed their own expertise and legalese in this field.

In 1948, G. M. Blackstock K.C., Chairman of the Board of Public Utility Commissioners, laid down what even to this date is called the "Blackstock formula" for fixing compensation payable by a pipeline company for an easement over land. ${ }^{89}$

A year later liability to a householder for damages caused by the escape of gas was settled. ${ }^{90} \mathrm{~A}$ disappointed Province of Alberta tried to increase its royalty share in contracts made before the transfer of natural resources to the province, and The Alberta Natural Resources Act had one of its first tests in court. ${ }^{91}$

A most prolific source of litigation about this time involved difficulties in land description. Alberta, proud of using the Torrens System, was in for a shock. Even the most foolproof system is no better than the people who operate it. The men and women who had charge of recording transfers and conveyances at the Edmonton and Calgary land offices were a dedicated lot, but no one in the early days had really put his or her mind to the differences between a transfer which said "Reserving all mines and minerals" and one that said "Reserving all coal and petroleum". But people now found out that different reservations meant different things, and for over a decade the courts were preoccupied with a great many cases interpreting the meaning of such phrases or deciding which title holder actually owned this or that mineral. I will only mention one or two of the more important ones.

One of the first was a battle by two farmers against Western Minerals Limited to decide whether sand and gravel belonged to them as owners of their farms, or came under the original reservation by the Company of

87a. S.A. 1947, c. 11.

88. Nadeau v. Cook [1948] 1 W.W.R. 284.

89. In re Pipe Line Act [1948] 2 W.W.R. 20.

90. Mortimer v. British America Oil Co. [1949] 2 W.W.R. 107; [1950] 1 W.W.R. 49.

91. Huggard Assets Ltd. v. A.G. for Alberta [1949] 2 W.W.R. 370; [1950] 1 W.W.R. 69. See The Alberta Natural Resources Act; S.A.1930, c. 21, and Amendment Acts, S.A.1931, c. 5. S.A. 1938, c. 14, S.A. 1941, c. 72, S.A. 1946, c. 2, S.A. 1951, c. 3 and S.A. 1962, c. 57. 
"mines, minerals and valuable stone". The two farmers lost at trial but came out on top in the end. Before their case had finally reached its ultimate resolution in the Supreme Court of Canada, their case produced special legislation. The Alberta Legislature, ever cognizant of the needs of the farm population, made history by enacting in The Sand and Gravel Act ${ }^{91 a}$ that no matter what the trial court had said the sand and gravel had, did and always would belong to the owner of the surface land. This case, therefore, also stands as a landmark decision on the supremacy of the legislature within its constitutional field.$^{92}$ This must have been one of the first pieces of Alberta legislation to withstand constitutional attack since 1935. The land company made an unprecedented move for petitioning the Governor General to disallow The Sand and Gravel Act as discriminatory. But by now the authorities in Ottawa no longer felt disposed to exercise their power of disallowance, resorted to during earlier days of bank tax acts and press bills. ${ }^{93}$

The very important issue of whether the term "petroleum" in a title reservation included natural gas was the next big battle. A farmer called Borys fought the Canadian Pacific Railway all the way to the Privy Council and won, establishing for the benefit of all landowners that even if he did not own the petroleum he had the gas. ${ }^{94}$

There were many cases in these years as to when an oil well's drilling began, whether the mechanics' lien legislation applied to the drilling, and so on. I do not propose to review all of these cases but one stands out in particular. This was Oil City Petroleums (Leduc) Ltd. v. A merican Leduc Petroleums $L t d .{ }^{95}$ Not only were some interesting legal precepts established in the related series of cases, but before the full sweep of the litigation had been exhausted the parties involved and their counsel could say they had been directly involved in historical events. The first was that the Wakefield case eventually ended up in the Privy Council in 1959, some ten years after Canada had abolished appeals to London, and so has the distinction of being Canada's last appeal to that august body ${ }^{96} \mathrm{~A}$ second highlight of these cases was that once again the flexibility of the Alberta judges was in evidence. This was illustrated by the approach taken by Chief Justice 0'Connor when Ponoka Calmar and American Leduc found their leases in danger of being cancelled because of the failure of Oil City to continue the drilling of offset wells. While appeals were being proceeded with, the Chief Justice took the unprecedented step of directing the Clerk of the Court to drill two wells pending the appeals. The writer, as counsel for Ponoka Calmar, had the pleasure of being in attendance when the Clerk brought his first well into production.

91a. S.A. 1951 , c. 77 .

92. Western Minerals $L t$. v. Gaumont (1951) 1 W.W.R. (N.S.) 369; (1951) 3 W.W.R. (N.S.) 434; [1953] 1 S.C.R. 345.

93. Morrow, W.G., "Disallowance" (1939) 3 Alta. L. Q. 83.

94. Borys v. Canadian Pacific Railway (1951)2 W.W.R.(N.S.) 145;(1951)4 W.W.R.(N.S.) 481; (1953) 7 W.W.R. (N.S.) 546.

95. Oil City Petroleums (Leduct Ltd. v. American Leduc Petroleums Ltd. (1951) 2 W.W.R. (N.S.) 371;[1951]3 D.L.R. 835;[1952]3 D.L.R. 577; Wakefield v. Oil City, (1957) 22 W.W.R. 267;[1958] S.C.R. 361; (1959) 29 W.W.R. 638; (1959) 3 W.L.R. 631;[1960] A.C. 18; (1960) 31 W.W.R. 376.

96. Morrow, W. G., "The Last Case" (1978) 16 Alta. L. Rev. 1. 
The discovery of gas was not always an absolute benefit, as may be seen in one reported case respecting Leduc Utilities Ltd. ${ }^{97}$ As more and more natural gas was discovered small towns and even farm homes came to be serviced with the product. Ironically, Leduc, which gave its name to the 1947 discovery well which brought it all about, had another distinction. When Leduc's line was connected to the town system a terrific explosion resulted and a substantial portion of the town was levelled, with loss of life and damage to property. Most of the claims were eventually settled, but certain of the litigants applied successfully to Mr. Justice McBride to have the case tried before a jury.

Perhaps the single most important legal case to emerge at this time was what lawyers call the Turta case. ${ }^{98}$ The issue here was as to the indefeasibility of the registered title under the Alberta Torrens land system and just how ineffective were attempts to correct errors in title made by land titles employees. Once this case had reached its final resolution in the Supreme Court of Canada, literally hundreds of lesser cases had to be litigated before the real owners of the land or the minerals could be ascertained.

Present during all of these years were the cases devoted to establishing what was fair compensation to the surface owner.$^{99}$

It is pleasing to note, also, that not all the emphasis was directed towards black gold. The Court of Appeal in 1952 was called upon to determine the constitutionality of the Canada Grain Act. ${ }^{100}$ In another reported decision a farm labourer was able to maintain a claim for damages against his employer for having him work on a defective combine tractor which, lacking safety devices, caused him serious disability. ${ }^{101} \mathrm{~A}$ small lawsuit came on for resolution before Judge McIssac of the District Court in 1952, relating to the sale of pulpwood. ${ }^{102}$

In 1954 even wills had to be adapted to refer to lease and royalty interests. The Appeal Court decided that a gift of "all proceeds" of oil leases to the widow was broad enough to include the bonus consideration paid for the lease itself. ${ }^{103}$

As the 1950's came to a close the events mirrored in the law reports showed little change. There were still cases resolving land titles errors respecting mineral title; ${ }^{104}$ attempts to circumvent the permit requirements under the Canadian Wheat Board Act; ${ }^{105}$ mortgage claims (but now with National Housing Loan Act and Regulations to consider with government intruding into one more avenue of enterprise); ${ }^{106}$ and attempts to tax pipelines. ${ }^{107}$

97. MacDonald v. Leduc Utilities Ltd. (1952) 7 W.W.R. (N.S.) 603.

98. Turta v. Canadian Pacific Ry. Co. (1952) 5 W.W.R. (N.S.) 529; (1954) 12 W.W.R.(N.S.) 97.

99. Ratz v. Strawberry Creek Coal Co. Ltd. (1952) 6 W.W.R. (N.S.) 145.

100. S.C. 1930, c. 5. See Adams v. Beaverlodge Grain Co. (1952) 6 W.W.R. (N.S.) 224.

101. Dambrowsky v. Olson (1952) 6 W.W.R. (N.S.) 493: (1953) 8 W.W.R. (N.S.) 716.

102. In re Dawby (1952) 6 W.W.R. (N.S.) 279.

103. In re Rigney Estate (1954) 12 W.W.R. (N.S.) 171.

104. Bouchard v. Registrar (1959) 27 W.W.R. (N.S.) 433.

105. R.S.C. 1952, c. 44. See R. v. Thumlert (1959) 28 W.W.R. (N.S.) 481.

106. Central Mortgage and Housing Corporation v. Ward (1957) 23 W.W.R. (N.S.) 319. See The National Housing Loans Act (Alberta), R.S.A. 1955, c. 220; National Housing Act, 1944, S.C. 1944, c. 46, R.S.C. 1952, c. 188; National Housing Act, 1954, S.C. 1953-54, c. 23.

107. Trans Mountain Oil Pipe Line Co. v. Jasper School District (1956) 19 W.W.R. (N.S.) 273. 
There were two cases which might be described as carryovers from the depression. In one a Mr. Schlaut tried to establish a claim to his old farm alleging an infirmity in the tax sale proceedings but he lost, the court holding he had abandoned the land in those old dry and impoverished years. ${ }^{108}$ The man's real objective was of course not to farm but to get the minerals. The second demonstrated just how hard it was for the government of the day, still to some extent imbued with the Aberhart philosophy, to let go of the debt problem. But once again, the new Orderly Payment of Debts Act passed in 1959 ${ }^{108 a}$ was struck down as in interference with the federal power over insolvency. ${ }^{109}$

Alberta's relationship with the Territories was alive as ever. The Appeal Court heard the Cardinal case which came down from Stipendiary Magistrate J. E. Gibben who had tried a murder charge with a jury at Aklavik. ${ }^{10} \mathrm{~A}$ new trial was ordered because of an improper direction respecting the test of insanity. This case is of interest as the retrial which took place before Mr. Justice J. B. McBride at Yellowknife some years later was, so far as I can gather, the last serious case to be handled under the old system. A new court known as the Territorial Court of the Northwest Territories was set up in 1955, so that all trials from that date were settled "north of Sixty".

\section{THE 1960's}

As Alberta's economy and development continued to expand and thrive through the Sixties the cases showed more and more variety in subject. There were still some of the old problems, but also some completely new issues which could never have been dreamed of in the earlier years.

In 1960 for example, Mr. Justice Riley had to settle a claim by a farmer against an oil company for damage to his water well caused by the effect of seismograph explosion as an exploration company roamed over his lands making tests of the formations below. ${ }^{111}$ This was indeed a change from the old antagonism to the railways. The need to expand waterworks and sewage disposal works brought on the inevitable clash with riparian owners who complained of having their water supplies contaminated. ${ }^{112}$

Of course a now affluent Alberta invited an accelerated battle between drivers charged with intoxication and the State. In one case a treaty Indian named Spear Chief found a road in an Indian Reserve was a highway within the High way Act. ${ }^{113}$ Even the Canadian Bill of Rights ${ }^{1133}$ was turned to by one irate drinker in an effort to prevent physical impairment tests to be used against him. I quote from the headnote of the report as I think it is a good sample of the judicial thinking at the time: ${ }^{114}$

108. Schlaut v. Northern Trusts Co. (1954) 12 W.W.R. (N.S.) 96.

108a. S.A. 1959, c. 61, repealed by Revision (1970).

109. Re Orderly Payment of Debts Act (1959) 29 W.W.R. (N.S.) 435.

110. R. v. Cardinal (1953) 10 W.W.R. (N.S.) 403.

111. Phillips v. California Standard Company (1960) 31 W.W.R. (N.S.) 331.

112. Howrish v. Holden (1960) 30 W.W.R. (N.S.) 491.

113. The Vehicles and Highway Traffic Act, R.S.A. 1955, c. 356, since repealed and superseded. See R. v. Spear Chief (1963) 45 W.W.R. (N.S.) 161.

113a. Enacted S.C. 1960, c. 44.

114. R. v. Martin (1961) 35 W.W.R. (N.S.) 385 . 
It is in society's interest that all crimes should be investigated, to the end of bringing criminals to justice, and such investigation should not be unduly hampered. But the object of such investigation should be to clear the innocent as well as to establish guilt....

There is no analogy between the taking by the police of physical tests (e.g., walking a straight line, etc.) and the taking of a statement from an accused person which is not voluntary, the fundamental difference being that in the latter case the statement may be untrustworthy. In the former case, evidence of the result of said tests is factual and given by lips other than the accused's. There is no burden on the crown, therefore, to establish that the taking of such tests was voluntary on the accused's part. ... There was nothing in the record of the proceedings herein regarding the admission of the evidence of physical tests which was contrary to sec. 2 (e) of the Canadian Bill of Rights, 1960 , ch. 44.

While Alberta's judicial connection with the Northwest Territories continued, a further step in the "repatriation" of the administration of justice to "North of Sixty" took place in 1960. No longer did appeals from the North go to Alberta's Appellate Divison. From now on the appeals were to the newly constituted Court of Appeal of the Northwest Territories, but the personnel making up the court, in addition to the Judges of the Northwest Territories and the Yukon, were the Alberta Appellate Judges. Quite appropriately the law reports record this important change. The very first case heard by this new court was at Yellowknife, a new first for the Appeal Court. It governed the principles to be followed in sentencing. Mr. Justice Hugh John MacDonald, speaking for the full court said: ${ }^{115}$

However it should be noted that in the present case the learned trial judge had a distinct advantage over the members of the court for with his wide experience in the far-flung areas of the extensive jurisdiction of the trial division of this court he has knowledge of local conditions, ways of life, habits, customs and characteristics of the race of people of which the accused is a member.

This was the Ayalik case and he was referring to the understanding $\mathrm{Mr}$. Justice Sissons had of the special problems which confronted Canada's Eskimo population.

In the early days of the former Alberta government the battle with land developers and farm mortgage foreclosures had prompted a special provision in Alberta law restricting recovery in land sales or mortgages to repossession or foreclosure of the land. ${ }^{116}$ The restriction prevented suing the debtor on his covenant for any balance owing in the event the land was of less value than the total debt. All through the depression years there were efforts to circumvent the restriction and although the success would have to be considered as somewhat divided, the application of the law has to be described as confused. But in the 1960's two cases went all the way to the Supreme Court of Canada with the result that some of the confusion disappeared. ${ }^{117}$

However, a new form of complication was emerging. This was development control and zoning with all that these terms connote. This new complication, brought about by the rapid urban and semi-urban expansion and by a realization of the importance of providing for environmental protection, resulted in a tremendous increase in administrative and municipal law. The proliferation of regulatory bodies had reached such almost epidemic proportions that the courts seemed to be unable to adequately handle other than the more important. But some remedy was

115. R. v. A yalik (1960) 33 W.W.R. (N.S.) 377.

116. Judicature Act, R.S.A. 1970, c. 193, s. 34(17).

117. Krook v. Yewchuk (1962) 39 W.W.R. (N.S.) 13; Edmonton Airport Hotel Co. Ltd. v. Credit Foncier (1965) 51 W.W.R. (N.S.) 431. 
necessary. In the result the office of Ombudsman was created by statute in 1967. ${ }^{118}$ And as might be expected, within three years we find a reported decision of Chief Justice Milvain ruling on the limits of the jurisdiction of Alberta's Ombudsman. ${ }^{119}$ This case referred to that official's right to investigate a decision of the Provincial Planning Board. The Chief Justice held he had such right. In 1969 the City of Edmonton found itself in trouble with U.S. developers named Webb and Knapp. The final answer came in the Supreme Court of Canada and was adverse to the City. ${ }^{120}$ This case involved an early plan for a civic centre.

By 1964 the petroleum industry had grown to the extent that clay and marl, mineral substances used in providing cementing materials required in drilling, had become important. Both the government of Alberta and the Canadian Pacific Railway had purported to lease these substances to a cement company, the claim being that they owned the minerals. A group of farmers affected went to court claiming that clay and marl made up the surface of their land and belonged to them. It was the old sand and gravel case, all over again. This time the government did not wait for a court decison. Instead it immediately passed The Clay and Marl Act ${ }^{120 a}$ which declared these substances had been and still were the property of the surface owner. To be fair, the government made the statute apply to its own vast holdings of mineral rights. The case of Imperial Cement $L t d$. $\mathrm{v}$. Schwindt was the final result, as Dechene J. had to resolve the issue of who got the rents and royalties from leases already executed and being operated under. ${ }^{121}$

Earlier in this article I mentioned the cases in which the need of gasoline for Sunday driving was recognized by the courts. With more time for relaxation and more money to support it, the needs of people were ever expanding, as seen in a 1966 judgment in which Turcotte J. extended the interpretation still further so as to include a coin-operated car wash. I quote from the headnote as it is a good example of how judges can rationalize from precedent to precedent: ${ }^{122}$

Appeal from the conviction by a magistrate of the appellant of conducting a coin-operated car wash on Sunday contrary to the Lord's Day Act. Appeal allowed.

It was held that the exception to be found in sec. 11 (o) of the Act, which permits "the hiring of horses and carriages or small boats for the personal use of the hirer or his family for any purpose not prohibited by this Act" has been extended by the authorities to include the motor car and the ancillary services required to operate it, including the sale of gasoline and oil, and washing facilities, among others. The analogy must be extended to include the operation as a separate business of the appellant's car wash....

By the sixties, while agriculture still remained important, the size of individual farms grew as many of the younger people left the land and moved to the brighter lights. One side effect was the acquisition of larger and larger parcels of land by such communal groups as Hutterites and Mennonites. Public pressure had led to the passing of The Communal Property Act in 1947 in an effort to control the acreage and the ownership of such

118. Ombudsman Act, S.A. 1967, c. 59.

119. Re Ombudsman Act (1970) 72 W.W.R. (N.S.) 176.

120. Webb \& Knapp (Canada) Ltd. v. Edmonton (1970) 72 W.W.R. 500.

120a. S.A. 1961, c. 14, R.S.A. 1970, c. 50.

121. Imperial Cement Ltd. v. Reginam and Schwindt (1964) 49 W.W.R. (N.S.) 111.

122. R. v. Mueller (1966) 55 W.W.R. 245. 
land. ${ }^{123}$ By 1965 the advent of Bills of Rights, a heavier accent on civil rights and anti-discrimination served to encourage attacks on legislation of this type. But the statute withstood the attack, it being held that in pith and substance the control was aimed more at tenure rather than an interference with religion. ${ }^{124}$

Regrettably the law reports in later years reflect that new social problem, drugs. Much of the time of the courts became taken up with attempts to restrict and punish narcotic abuse. Mr. Justice $\mathrm{H}$. Riley held that provincial legislation regarding hallucinogenic drugs was constitutional. ${ }^{125} \mathrm{In}$ a decision dated October 18, 1967 the appeal court attempted to lay down certain principles governing what sentences should be imposed. ${ }^{126} \mathrm{Later}$, in 1970, the same court in Regina v. Doyle examined eleven different drug cases and once again tried to lay down principles to follow. ${ }^{127}$ In essence the court said that deterrence had to be the governing principle. Five years later another omnibus judgment is to be found, once again emphasizing deterrence. ${ }^{128}$ The fact that this question occupied so much of the court's attention reflects how social conditions were developing.

\section{CONCLUSION}

As we came closer to Alberta's seventy-fifth year more and more litigation arose from the status of women. In 1980 , for example, a case came on for hearing before the court to test the applicability of the provincial Individual's Rights Protection Act ${ }^{128 a}$ to the Canadian Pacific Railway, but the latter won on the ground that the right to create anti-discriminatory legislation against a railway fell into the federal sphere. ${ }^{129}$ In a much publicized case, Murdoch v. Murdoch, ${ }^{130}$ a wife lost her claim for a beneficial interest in her husband's ranch property despite evidence that she had contributed her own labour in helping her husband acquire the assets. But no doubt this case, applying the law as the Supreme Court of Canada saw it, did contribute to the passage of legislation more favourable to Alberta's women. I refer here to the Matrimonial Property Act passed in 1978. ${ }^{131}$

By the end of the period under review the social conscience had reached the stage where compensation could be sought by the innocent victims of crime and in 1977, for example, the Appellate Division decided that the compensation statute included a claim put forth by a person injured while attempting to prevent a crime..$^{132}$

123. S.A. 1947, c. 16; repealed by Communal Property Repeal Act, S.A. 1972, c. 103, s. 1.

124. Walter v. A.G. for Alberta (1967) 58 W.W.R. 385.

125. R. v. Snyder (1967)61 W.W.R. 112; the legislation in question was The Public Health Act, R.S.A. 1955 , c. 255, s. 42.

126. R. v. Lehrmann (1967) 61 W.W.R. 625.

127. R. v. Doyle [1971] 1 W.W.R. 70.

128. R. v. Sprague [1975] 1 W.W.R. 22.

128a. S.A. 1972, c. 2, as am..

129. C.P.R. v. A.G. for Alberta (1980) 11 Alta. L.R. (2d) 200.

130. Murdoch v. Murdoch [1974] 1 W.W.R. 361.

131. The Matrimonial Property Act, S.A. 1978, c. 22.

132. Willier v. Crimes Compensation Board (1977)2 Alta. L.R. (2d) 25. The statute under consideration was The Criminal Injuries Compensation Act, R.S.A. 1970, c. 75, as am.. 
Before closing I think it only appropriate to refer to two fairly recent decisions of the Court of Appeal. The first was a case decided in 1980 in which a caveat restricting the use of land within the City of Edmonton was held to still be valid, thus halting more intensive housing development, for the moment at any rate. ${ }^{133}$ The case is interesting as the caveat had been put on a portion of the old Hudson's Bay Reserve by that venerable old company which has had so much to do with our history, namely The Governor and Company of Adventurers of England Trading into Hudson's Bay. The reserve represented a portion of the land kept by the Company and to which it was entitled as land adjacent to old Fort Edmonton, as authorized by the Rupert's Land Act, 1868. ${ }^{133 a}$ This Act covered the transfer to the Dominion of what was to become the Northwest Territories and from which Alberta was carved. We do have an interesting history.

Before leaving the last decade it is interesting to note that in 1967, one of the Aberhart "experiments", the Alberta Treasury Branch system, set up throughout the province to give the smaller centres a banking service, came under fire in the courts. The constitutionality of the Treasury Branches was attacked but the courts found a way to resolve the issue without settling the ultra vires question. ${ }^{134}$

Now that Alberta has become important in the energy sense an offshoot.of the oil and gas industry has been the export not only of the products but also of the expertise in searching for these elusive but valuable substances. And so as we close our study of the first seventy-five years, reference must be made to a decision of the court where an international situation was litigated. A Norwegian ship equipped to search for petroleum products offshore ran on the rocks off Capetown, South Africa. Quite fittingly, the litigation emerged in our courts as the exploration company was based in Calgary. ${ }^{135}$ Our province has moved some distance when this type of case can now come up.

And in January 1980 a constitutional case, of some portent to the future, was heard in the Court of Appeal. The issue was with respect to the jurisdiction of the Alberta energy board to empower Calgary Power to build a major transmission line to within a few inches of the B.C.-Alberta border..$^{136}$ No doubt our courts will see more of these in the last quarter of Alberta's first hundred years.

We have seen how through the years the type of cases before the courts has changed to reflect the changes in the economy and in the social culture. But at the same time there has been a thread of consistency as well: for example, the farm problems have changed little.

In summary, I have made a tally of the reported cases in the first twelve months of Alberta's history. Out of forty-six cases reported, five related to contract; six were in the criminal field; seven were concerned with fights between creditors and their debtors; four were land cases; one a

133. Seifeddine v. Governor and Company of Adventurers of England Trading into Hudson's Bay (1980) 11 Alta. L.R. (2) 229.

133a. (U.K.), 31 \& 32 Vict., c. 105.

134. Breckenridge Speedway Ltd. v. Reginam (1967) 61 W.W.R. 257; (1969) 70 W.W.R. 481.

135. Karlsen Shipping Company Ltd. v. Sefel J. \& A ssociates Ltd. (1979) 7 Alta. L.R. (2d) 13.

136. Fulton, Friesz et al. v. Energy Resources Conservation Board [1980] 3 W.W.R. 176. 
mortgage; one concerned liquor and a treaty Indian; and two dealt with land sales. The remaining cases covered a wide range, all the way from a lawyer sued for misappropriation of funds to the C.P.R. accused of negligence. Now let us see what difference the seventy-fifth year shows, if any. One hundred and twenty-six cases show up in the reports in this last year. The greater number, when compared to 1905 , to some extent can be attributed to a greater population. But changes in our way of life have also contributed. Eight deal with contracts; thirteen are of the criminal type; creditors fighting with debtors still show up as important, there being six; once again, too, there were five relating to land; one mortgage; the Indian cases are still there, two this time; and finally there were two land sale decisions. But the new times show many new subjects. To name but a few: two cases refer to administrative boards; one concerns tax donations to a church; three cover constitutional issues; six now deal with divorce; one with defamation; five with insurance; twelve are battles between citizens and a municipal body; there are two more involving labour unions; four relate to battles between farmers and oil companies over compensation for surface use; and even University tuition fees have been subjected to a court ruling.

If one goes far enough back in the English law reports, cases will be found which illuminate past social and political issues by discussing whether trial by ordeal was still legal and who owned flint and saltpetre, so necessary in those days of threat by Napoleon. Similarly we see in the preceding pages almost every aspect of the life lived through during the relatively short span of Alberta's seventy-five years, and the struggles of her peoples. Each new phase of development called for challenge and each new pressure invited its own test, and these challenges and tests were fought out in the courts. 